\title{
Antibacterial activities of the essential oil and hydroethanolic extract from Aeollanthus heliotropioides Oliv
}

\author{
François Nguimatsia ${ }^{1}$, Sidonie Beatrice Kenmogne ${ }^{2}$, Madeleine Nina Love Ngo-Mback ${ }^{3}$, , Jonas \\ Kouamouo ${ }^{1}$, Léa Larissa Nzenti Tchuitio ${ }^{1}$, Yannick Kevin Melogmo Dongmo ${ }^{4}$ and Pierre Michel Jazet \\ Dongmo 5 \\ ${ }^{1}$ Université des Montagnes, BP 208, Bangangté, Cameroon \\ ${ }^{2}$ Laboratory of Chemistry, Department of Chemistry, University of Douala, PO Box 24157, Douala, Cameroon \\ ${ }^{3}$ Institute of Fisheries and Aquatic Sciences (ISH)-Yabassi, University of Douala, PO Box 24157, Douala, \\ Cameroon \\ ${ }^{4}$ Antimicrobial Agents Unit, Laboratory of Phytobiochemistry and Medicinal Plants Studies, Department of \\ Biochemistry, Faculty of Science, University of Yaoundé I, PO Box 812, Yaoundé, Cameroon \\ ${ }^{5}$ Laboratory of Biochemistry, Department of Biochemistry, University of Douala, PO Box 24157, Douala, \\ Cameroon
}

\begin{abstract}
To control bacterial infections, we proposed evaluating the antibacterial activities and modes of action of Aeollanthus heliotropioides essential oil and its hydroethanolic extract. Solvent extracts and essential oil were obtained from the aromatic plant's aerial parts by hydroethanolic maceration and hydro-distillation. The analyses of the chemical composition were performed using gas chromatography coupled with mass spectrometry. The microdilution method evaluated the in vitro antibacterial potential of the essential oil and solvent extracts. The Inhibition of biofilms formation was carried out using a colorimetric biofilm microdilution assay with crystal violet as a dye. The effect of extract and essential oil on the release of nucleic acids was performed using a spectrophotometric method. The time-kill kinetic assay was assessed for hydroethanolic extracts and essential oil. The extraction yield was $0.1 \%$, and the major compounds identified in the essential oil were linalool (43.47\%) and cis- $\alpha$-farnesene $(42.67 \%)$. The phytochemical screening revealed flavonoids, saponins, phenols, triterpenes, catechin tannins, and quinones. Minimum Inhibitory Concentrations (MICs) ranged from $2.08 \mathrm{mg} / \mathrm{mL}$ to 10 $\mathrm{mg} / \mathrm{mL}$. Concerning the modes of action, the essential oil showed its bactericidal effect at 2 hours. The reduction of Escherichia coli biofilms formation was found at $0.21 \mathrm{mg} / \mathrm{mL}$. The essential oil treatments resulted in a release of nucleic acids at a concentration of $2.1 \mathrm{mg} / \mathrm{mL}$. These results justify using the essential oil and hydroethanolic extracts of Aeollanthus heliotropioides as a potential source of molecules with antibacterial activity.
\end{abstract}

Keywords: Aeollanthus heliotropioides; essential oil; hydroethanolic extract; antibacterial activity; modes of action.

\section{Introduction}

Infectious diseases result from the interaction between infectious agents, the host, and environmental factors ${ }^{1}$. The emergence of pathogens remains a major public health problem, with around 10 million deaths each year, mainly affecting tropical countries 2,3 . Among these infectious diseases, those of bacterial origin account for $90 \%$. These infections remain one of the major causes of mortality and morbidity in developing countries, with the emergence of resistance appears as the primary cause of antibacterial treatment failure ${ }^{4}$.

Despite the endeavors involved to fight bacterial infections, bacteria continue to manifest many resistance mechanisms ${ }^{5}$. Biofilm formation is a resistance feature developed by bacteria to avoid or diminish the efficacy of antimicrobial treatments ${ }^{6}$. Biofilms are sets of microbial communities that constitute a complex three-dimensional structure, bathing inside a matrix and helping microorganisms strengthen their pathogenicity. This matrix is made of polysaccharides, proteins, and other organic components ${ }^{7}$. There are other cell features of bacteria to bypass the effect of antimicrobials, among which are cell walls and cell membranes. They represent

ideal cidal targets because they lead to bacteria disruption, which considerably affects the cell viability. On the other hand, the cell wall synthesis is conserved across bacterial pathogen generations, and

*Corresponding author: Madeleine Nina Love Ngo-Mback Email address: ngombackmanilo@yahoo.fr

DOI: http://dx.doi.org/10.13171/mjc02102021555mnlnm
Received October 29, 2020

Accepted November 27, 2020

Published February 2, 2021 
it is absent from mammalian cells ${ }^{8-10}$. All these considerations have initiated the search for new antiinfectious agents from different sources ${ }^{11}$.

The use of medicinal plants represents a potent alternative. The World Health Organization (WHO) also recognized the importance of medicinal plants by stating that $80 \%$ of the world's population depends on traditional medicine for primary health - care ${ }^{12}$. Many studies are being done on traditional medicine plants to search for new secondary metabolites with activity against infectious agents. It is worth noting that plants are a rich source of bioactive compounds, including potent antimicrobial activities ${ }^{13}$. Moreover, some local treatments with aromatic plants are used in some cases to face microbial infections ${ }^{14,15}$.

Aeollanthus heliotropioides (A. heliotropioides) Oliv from the Lamiaceae family, with the synonym Aeollanthus Suaveolens Mart. ex Spreng is a traditional condiment used to season roasted fish and meat. The therapeutic properties of A. heliotropioides such as antimicrobial and antioxidant have been demonstrated ${ }^{16-18}$. However, antibacterial modes of action on this plant are not well studied. This work aimed to evaluate the antibacterial activities and modes of action of $A$. heliotropioides hydroethanolic extracts and its essential oil. The modes of action were focused on the cell membrane and biofilms formation.

\section{Experimental}

Fresh flowers, stems, and leaves of A. heliotropioides were collected from Mfoundi market, Yaoundé, Cameroon. The identification was made at the National Herbarium of Cameroon (HNC) by comparing the previous sample under the Herbarium collection-number $42756 \mathrm{HNC}$. The bacterial strains used for the susceptibility tests were Escherichia coli ATCC25502, Salmonella enterica NR 4311, Klebsiella pneumoniae NR4119, Staphylococcus aureus NR 46375, and Salmonella typhi, an isolate from Laboratory of Phytobiochemistry, University of Yaoundé I, Cameroon.

\subsection{Extraction of the essential oil}

The collected plant parts were successively submitted to a 4 hours hydro-distillation using a Clevenger type apparatus. For each part, essential oils were separately collected by decantation, dried under an anhydrous sodium sulphate column, and stored at $4^{\circ} \mathrm{C}{ }^{19}$.

\subsection{Hydro-ethanolic extracts preparation}

Secondary metabolites extraction was successively performed on A. heliotropioides stems, leaves, and fresh flowers. The plant dry powder $(200 \mathrm{~g})$ was macerated in $30 / 70$ water/ethanol $(1000 \mathrm{~mL})$ at room temperature for 72 hours. Organic solvents were subsequently evaporated from filtrates using a rotary evaporator (Büchi 011, Flawil Switzerland) and lyophilized. Each plant powder was extracted separately two times. The extraction yields were calculated according to the following equation:

Extraction yield $(\%)=\frac{\text { Extract }(\mathrm{g})}{\text { Vegetal material }(\mathrm{g})} \times 100$

\subsection{Phytochemical screening of plant extracts}

Plant extracts were submitted to a qualitative chemical analysis to identify secondary metabolites responsible for the antibacterial activity. These secondary metabolites include flavonoids, tannins, alkaloids, glucosides, saponins, triterpenes, anthocyanins, and phenols. Chemical tests were performed using colorimetric methods according to the protocols previously described ${ }^{20-23}$. Stock solutions of hydroethanolic extract were prepared at a concentration of $5 \mathrm{mg} / \mathrm{mL}$. Then, each extract solution was used for the corresponding colorimetric assay to be performed.

\subsection{Analysis of the chemical composition of the essential oil}

The chemical composition analyses were performed using Gas chromatography (GC)-mass spectrometry (MS) analysis. GC-MS analyses were performed using a Hewlett Packard apparatus equipped with an HP1 fused silica column (length $30 \mathrm{~m}$; film thickness $0.25 \mathrm{~mm}$ ) and interfaced with a quadruple detector (Model 5970). The column temperature was programmed from $508^{\circ} \mathrm{C}$ to $2008^{\circ} \mathrm{C}$ at $58^{\circ} \mathrm{C} / \mathrm{min}$; injector temperature was $2208^{\circ} \mathrm{C}$. Helium was used as carrier gas at a flow rate of $0.6 \mathrm{~mL} \cdot \mathrm{min}^{-1}$; the mass spectrometer was operated at $70 \mathrm{eV}$. Two microliters of diluted samples (10/100, v/ v, in methylene chloride) were injected manually in the split mode (1/100). Identifying individual compounds was based on comparing their relative retention times and their mass spectra of peaks with those obtained from authentic samples on libraries and published data ${ }^{24}$.

\subsection{Determination of Minimum Inhibitory Concentrations (MIC) and Minimum Bactericidal Concentrations (MBC)}

The inhibitory parameters were determined using the 96-wells microtitre plate format. The experiments were assessed according to the Clinical Laboratory Standards Institute (CLSI) M7-A9 microdilution method ${ }^{25}$. Volumes of $196 \mu \mathrm{L}$ and $100 \mu \mathrm{L}$ of sterile Mueller Hinton Broth were introduced in the first 12 wells and in the plate's remaining wells. Then, $4 \mu \mathrm{L}$ diluted extracts in Muller Hinton Broth (MHB) were introduced in the plate's previous 12 wells, and series of dilutions were performed ranging from $0.156-10$ $\mathrm{mg} / \mathrm{mL}$ for the plant extracts and from $0.031-2 \mathrm{mg} / \mathrm{mL}$ for ciprofloxacin. After that, $100 \mu \mathrm{L}$ of the bacterial inoculum standardized at $5 \times 10^{5}$ cells $/ \mathrm{mL}$ as final concentration were added to each well containing the test substances except for the blank column for sterility control. The negative control was constituted of MHB and the inoculum. After an incubation of $24 \mathrm{~h}$ at $37^{\circ} \mathrm{C}, 10 \mu \mathrm{L}$ of resazurin $(0.1 \mathrm{mg} / \mathrm{mL})$ was 
used for results revelation. The lowest concentration without any color change was considered as the MIC. For Minimum Bactericidal Concentrations (MBC), 25 $\mu \mathrm{L}$ from MIC wells were transferred in $175 \mu \mathrm{L}$. After $48 \mathrm{~h}$ of incubation at $37^{\circ} \mathrm{C}$, MBC was revealed as previously described using resazurin. All the experiments were performed in triplicate.

\subsubsection{Inhibition of bacterial biofilms formation}

A series of sub-inhibitory concentrations of plant extracts were tested against bacterial biofilms formation. A microtitre plate biofilm assay as described in previous works 19,26 with some modifications was used. An amount of $100 \mu \mathrm{L}$ from overnight cultures of bacteria was added into $100 \mu \mathrm{L}$ of fresh MHB supplemented with $6 \%$ glucose and cultivated in the presence or absence of plant extracts. Microtitre plates were then incubated for $48 \mathrm{~h}$ at $37^{\circ} \mathrm{C}$. The wells containing MHB + cells served as control. After incubation, the wells were washed with distilled water to remove planktonic cells. The remaining sessile cells were subsequently stained with $0.1 \%$ crystal violet solution for $20 \mathrm{~min}$ at room temperature. The wells were washed once again to remove crystal violet. The plates were dried at room temperature for $2 \mathrm{~h}$ followed by $250 \mu \mathrm{L}$ of $33 \%$ glacial acetic acid into the wells. After $20 \mathrm{~min}$, the optical density (OD) of each well was measured at $590 \mathrm{~nm} \mathrm{(96} \mathrm{wells}$ microtitre plate reader TECAN Infinite M200). The obtained ODs at $590 \mathrm{~nm}$ was plotted against the corresponding extract concentrations.

\subsubsection{Membrane impairment: effect on nucleic acids release}

The impact of active extracts on the membrane was carried out according to the protocol described by Tang ${ }^{27}$. Bacterial cells were washed and suspended in $10 \mathrm{mM}$ PBS (pH 7.4). Extract solutions were prepared at inhibitory concentrations of MIC, $2 \mathrm{MIC}$, and $4 \mathrm{MIC}$ and introduced to a $10 \mathrm{mM}$ PBS solution containing bacteria cells at a concentration of $5.10^{5}$ UFC / $\mathrm{mL}$. The preparation was incubated, and ODs were read at different periods $(0 \mathrm{~h}, 4 \mathrm{~h}, 8 \mathrm{~h}$, and $12 \mathrm{~h}$ ). The control assay was constituted of bacteria cells and the 10mM PBS solution. After each incubation period, the mixture was centrifuged at $10000 \mathrm{rpm}$, and the absorbance of the supernatant was determined using a spectrophotometer reader at $260 \mathrm{~nm}$. The loss of nucleotides served as an indicator of significant damages to cell membranes.

\subsection{Time kill kinetic assay}

To determine the required time for antimicrobial extracts to inhibit the cells growth, a time-kill kinetic test (tkk) was performed according to the previous studies with some modifications ${ }^{28}$. The culture medium was introduced into eppendorfs. Active antimicrobial substances and ciprofloxacin were added to the MHB medium to obtain subinhibitory concentrations (MIC/6, MIC/8, and $\mathrm{MIC} / 10)$. The obtained solutions were homogenized, and a bacterial suspension was inoculated to reach a bacterial charge of $5 \times 10^{5} \mathrm{UFC} / \mathrm{mL}$. The preparation was incubated at $37^{\circ} \mathrm{C}$. After $24 \mathrm{~h}$, at specific periods $(0 \mathrm{~h} ; 2 \mathrm{~h} ; 5 \mathrm{~h}$; $8 \mathrm{~h}, 11 \mathrm{~h}, 24 \mathrm{~h})$, ODs were read using a microtitre plate reader (TECAN Infinite M200) at $630 \mathrm{~nm}$. The tkk curves were drawn as ODs versus incubation time units.

\subsection{Statistical analysis}

All experiments were performed in triplicate. The results were statistically analyzed by ANOVA and least sensitive difference (LSD) with Fisher test at 5\% threshold probability factor using STAGRAPHICS plus 5.0 software for Windows.

\section{Results and discussion}

\subsection{Extraction yields of the essential oil and solvent extracts}

The extraction yield of the essential oil was $0.1 \%$. The oil was in the form of a clear yellow liquid with a coconut odor.

These results corroborate other reports ${ }^{16}$, which obtained a yield substantially close $(0.07 \%)$. However, there is a difference with the results from other studies with a yield of $1.3 \%{ }^{29}$. The variation observed in the extraction yield could be due to many factors, including the effect of the climate variation, the nature of the geographical site, the quality of the soil, and the harvesting period, which could impact the quality and amount of the volatile fraction.

\subsection{Chemical analysis}

\subsubsection{GC-MS of the essential oil}

The chemical composition of A. heliotropioides essential oil (Table 1) revealed linalool $(43.47 \%)$ and cis- $\alpha$-farnesene $(42.67 \%)$ as major compounds. The presence of monoterpenes and sesquiterpenes were also identified in a proportion of $44.95 \%$ and $55.05 \%$, respectively.

\subsubsection{Phytochemical screening of stem, leaf, and flower hydroethanolic extracts}

Secondary metabolites that were qualitatively identified are listed in Table 2.

From the above Table 2, flower extracts have shown great diversity in secondary metabolites. Flavonoids, saponins, triterpenes, catechin tannins, and quinones were identified. Concerning leaf extracts, the same metabolites as of flower extracts were also identified except for quinones. But, only flavonoids and saponins were identified in stem extracts.

The essential oil analysis by GC/MC highlighted linalool $(43.47 \%)$ and cis- $\alpha$-farnesene $(42.67 \%)$ as major compounds. These compounds were the same as those obtained in the review; $38.5 \%$ for linalool and $25.1 \%$ for cis- $\alpha$-farnesene ${ }^{16}$ then $34.9 \%$ and $29.1 \%$ for linalool and farnesene ${ }^{29}$. This difference could be explained by the geographical origin of the plant, the organ used for the extraction (leaf, stems, or 
flowers...), the environmental factors, and the

extraction process applied to the plant ${ }^{30}$.

Table 1. Chemical composition of A. heliotropioides essential oil.

\begin{tabular}{|c|c|c|}
\hline Kovats Index & Compound name & Area (\%) \\
\hline Monoterpenes & & 44.5 \\
\hline Hydrocarbonated monoterpenes & & 1.48 \\
\hline 813 & $\alpha$ - pinene & \\
\hline Oxygenated monoterpenes & & $\mathbf{4 3 . 4 7}$ \\
\hline $\mathbf{8 7 0}$ & Linalol & 55.05 \\
\hline Sesquiterpenes & & \\
\hline Hydrocarbonated sesquiterpenes & $\beta$-caryophyllene & 9.32 \\
\hline 1011 & cis- $\alpha$-bergamotene & 0.51 \\
\hline 1017 & cis- $\alpha$-farnesene & $\mathbf{4 2 . 6 7}$ \\
\hline $\mathbf{1 0 2 1}$ & $\beta$-copaene & 2.55 \\
\hline 1032 & & \\
\hline
\end{tabular}

Table 2. Phytochemical composition of the crude extracts obtained from the stems, leaves, and flowers of $A$. heliotropioides.

\begin{tabular}{|c|c|c|c|}
\hline & Stem extract & Leaf extract & Flower extract \\
\hline Flavonoids & + & + & + \\
\hline Saponins & + & + & + \\
\hline Phenols & - & + & + \\
\hline Triterpenes & - & + & + \\
\hline Catechin tannins & - & - & + \\
\hline Quinones & - & - & - \\
\hline Alkaloids & - & - & - \\
\hline Glucosides & - & - & - \\
\hline Anthocyanins & - & & + \\
\hline
\end{tabular}

Presence + absence -

Table 3. MIC and MBC values of plant extracts.

\begin{tabular}{|c|c|c|c|c|c|c|c|c|c|c|c|c|}
\hline \multirow{4}{*}{$\begin{array}{l}\mathbf{S}^{\mathbf{a}} \\
E \boldsymbol{C}^{b}\end{array}$} & \multicolumn{12}{|c|}{ Plant extracts - MIC and MBC (mg/mL) } \\
\hline & \multicolumn{3}{|c|}{$\mathbf{E} 1^{\text {h }}$} & \multicolumn{3}{|c|}{$\mathbf{E} 2^{\mathbf{i}}$} & \multicolumn{3}{|c|}{$\mathbf{E 3}^{\mathbf{j}}$} & \multicolumn{3}{|c|}{$\mathbf{E} 4^{\mathrm{k}}$} \\
\hline & MIC & MBC & ratio & MIC & MBC & ratio & MIC & MBC & ratio & MIC & MBC & ratio \\
\hline & 10 & $>10$ & - & 10 & $>10$ & - & 2,08 & 10 & 4,80 & 2,08 & 10 & 4,80 \\
\hline$S c^{3}$ & 10 & $>10$ & - & 10 & $>10$ & - & 2,08 & 10 & 4,80 & 4,16 & 10 & 2,40 \\
\hline$S E^{d}$ & 10 & $>10$ & - & 10 & $>10$ & - & 2,08 & 10 & 4,80 & 4,16 & 10 & 2,40 \\
\hline$S T^{e}$ & $>10$ & $>10$ & - & $>10$ & $>10$ & - & 5 & 10 & 2 & 2,5 & 10 & 4 \\
\hline $\boldsymbol{K} \boldsymbol{P}^{f}$ & $>10$ & $>10$ & - & 5 & $>10$ & - & 2,5 & 10 & 4 & 2,5 & 10 & 4 \\
\hline
\end{tabular}

Legend ( ${ }^{\mathrm{a}}$ : Bacterial strains; ${ }^{\text {b}}:$ E. coli; ${ }^{\text {c: }}$ S. aureus; ${ }^{\mathrm{d}}$ : S. enterica; ${ }^{\mathrm{e}}:$ S. thyphii; ${ }^{\mathrm{f}}:$ K. pneumonia; ${ }^{\mathrm{g}}$ : No determined; h. stems extract; i: leaves extract; ${ }^{\mathrm{j}}$ : flowers extracts; ${ }^{\mathrm{k}}$ : Essential oil; ratio: MBC/MIC). 


\subsection{Antimicrobial activity}

3.3.1. Hydroethanolic extracts and essential oil inhibitory concentrations

The results obtained gave MIC values ranging from $2.08-10 \mathrm{mg} / \mathrm{mL}$. Flower extracts and EO exhibited the highest activity up to $2.08 \mathrm{mg} / \mathrm{mL}$. The most susceptible strain was $E$. coli inhibited at $2.08 \mathrm{mg} / \mathrm{mL}$ by flowers solvent extract, and EO. $S$. aureus and $S$. enterica were both inhibited at $4.18 \mathrm{mg} / \mathrm{mL}$ by the plant extracts. The less susceptible bacterium was $S$. thyphii with a MIC at $5 \mathrm{mg} / \mathrm{mL}$. The other extracts showed an activity at a concentration greater than $10 \mathrm{mg} / \mathrm{mL}$ or equal to $10 \mathrm{mg} / \mathrm{mL}$ (Table 3 ).

The flowers extract bactericidal on $S$. typhii with an MBC/MIC ratio of 2, while EO exhibited a bactericidal effect on $S$. aureus with an MBC/MIC lower than 4 .

Each extract and the EO's antibacterial activity is characterized by MIC values ranging from 2.08-10 $\mathrm{mg} / \mathrm{mL}$ on the bacterial strains. The chemical content of plant extracts was responsible for the observed activity. The phytochemical screening showed that the leaf and flower extracts have almost the same composition. The presence of flavonoids, saponins, triterpenes, catechins, and tannins was identified in both extracts. Its greater diversity could explain the highest activity of flower extracts in secondary metabolites than the other extracts. These secondary metabolites could act synergistically and exhibit a potent antibacterial action of the extract ${ }^{19}$. The essential oil has also shown better antibacterial activity on E. coli, S. aureus, K. pneumoniae, and Salmonella than the one obtained by some researchers. They got $1.25 \mathrm{mg} / \mathrm{mL}$ for $E$. coli and $10 \mathrm{mg} / \mathrm{mL}$ for $S$. aureus, Klebsiella $s p$.. In addition, Some authors obtained MICs of 50, 100, and $50 \mathrm{mg} / \mathrm{mL}$ respectively for $E$. coli, $S$. aureus, and Salmonella sp. ${ }^{17,29}$. These differences in MIC concentrations could be due to monoterpenes and sesquiterpenes that are in a high proportion in EO. Terpenes compounds could cause more damage to the bacterium's cell membrane and, after that affecting equilibrium and ionic homeostasis ${ }^{31}$. In the same way, previous studies indicate that this hydrophilic surface is a barrier that prevents the entry of antibiotics into the cell ${ }^{32}$.

The above MIC results highlighted E. coli as the most susceptible bacterial strain. Thus, all the antibacterial modes of action were performed against its pathogenic features.

\subsubsection{Inhibition of biofilm formation}

The Inhibition of $E$. coli biofilms formation is reported below in Figure 1.

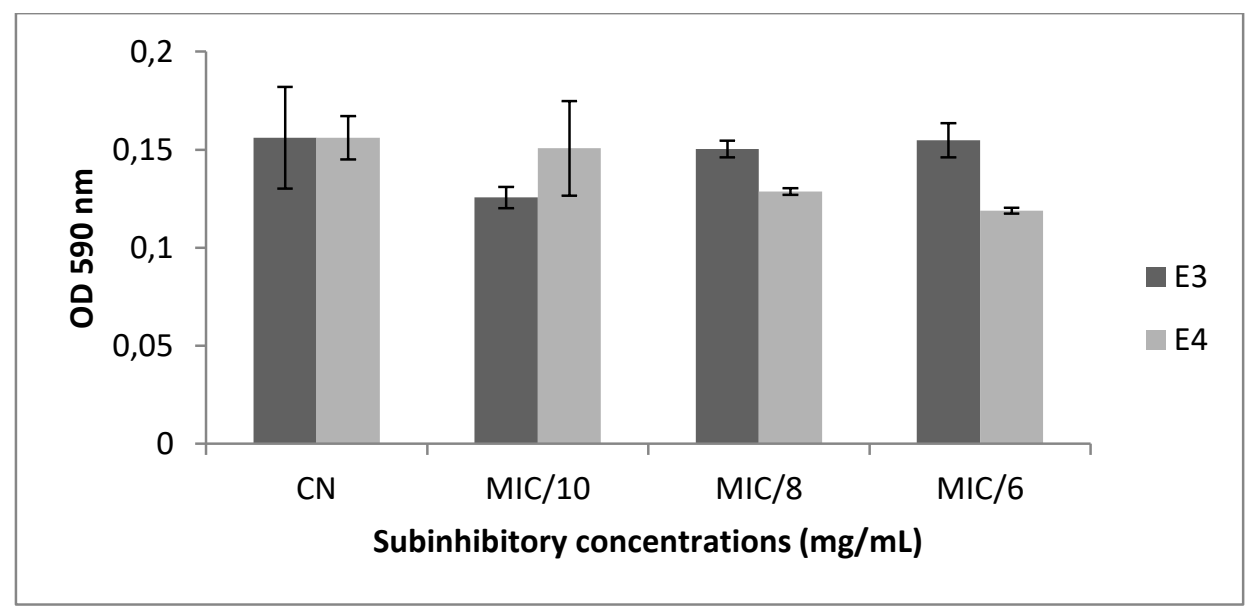

E3: flowers extracts; E4: essential oil; $\mathrm{CN}$ : growth control

Figure 1. Inhibition of $E$. coli biofilms by flower extracts and $\mathrm{EO}$ at sub-inhibitory concentrations

Figure 1 shows the decrease of $E$. coli biofilm formation when treated with flower extracts and EO compared to the growth control. Indeed, it is observed that EO has led to a reduction in the amount of biofilms. The biofilms reduction is expressed by a decrease of optical densities from $0.15,0.13$ to 0.12 at $0.2 \mathrm{mg} / \mathrm{mL}, \quad 0.25 \mathrm{mg} / \mathrm{mL}$ and $0.33 \mathrm{mg} / \mathrm{mL}$ respectively. The flower extracts did not influence the amount of biofilms formed as they remained substantially close to the control.

The inhibition of $E$. coli biofilms formation by EO and flower extracts has shown that, just like the growth control, the flower extract cannot prevent the formation of biofilms. In comparison to the EO, it was able to reduce the biofilms formed. In our knowledge, no studies have been made with the essential oil of $A$. heliotropioides on the Inhibition of the formation of bacterial biofilms. However, some studies have shown that the peppermint essential oil of Lamiaceae family prevents $E$. coli-forming biofilms ${ }^{33}$. This could be related to the fact that some natural substances could act through the destruction of biofilms, mainly by targeting bacterial adhesins, which are antigens expressed during the initial adhesion of the biofilm ${ }^{34}$. 


\subsubsection{Time kill}

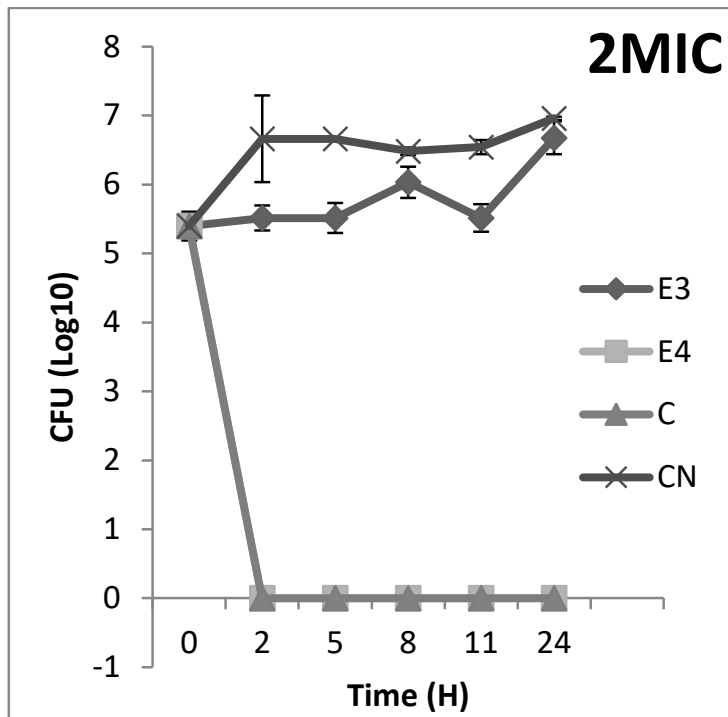

Inhibition of E. coli by $\mathrm{EO}$ and flower extracts is shown in Figure 2.

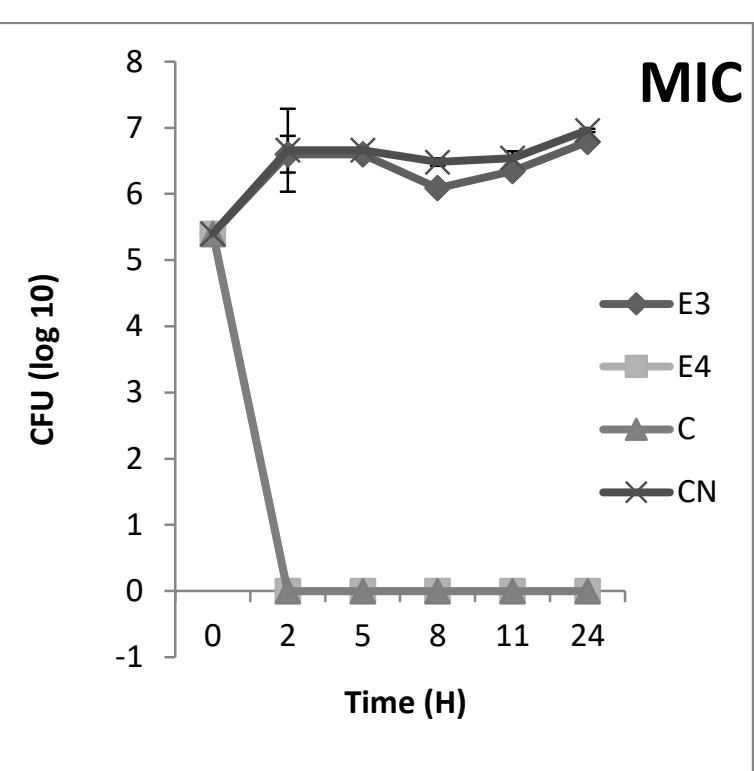

E3: flower extracts; E4: essential oil; CN: growth control; C: ciprofloxacin

Figure 2. Inhibition of E. coli growth by flower extracts and EO as a function of time at supra inhibitory and inhibitory concentrations (2MIC and MIC)

The above graphs represent the inhibition effect of flower (E3), and essential oil (E4) extracts on E. coli at the supra-inhibitory (2MIC) and inhibitory (MIC) concentrations as a function of time. Indeed, a decrease in bacterial load of more than $5 \log 10$ from $2 \mathrm{~h}$ up to $24 \mathrm{~h}$ in the presence of essential oils was observed. Also, there was a significant difference between the negative control and the tested extracts (P-value<5\%).

The evaluation of mortality kinetics allowed tracking bacterial mortality over time. The results revealed that
EO and ciprofloxacin caused a decrease in bacterial load until $0 \log 10$ after $2 \mathrm{~h}$. This suggests that EO may have a bactericidal effect such as ciprofloxacin, the reference medicine used as a control. This observation agrees with the review that showed that ciprofloxacin is bactericidal (capable of causing a cidal effect of $99.9 \%$ on bacteria) on gram-negative bacilli in a short time after contact with cells ${ }^{35}$.

\subsection{4. release of nucleic acids}

The release of nucleic acids by the action of active extracts is shown in Figure 3 below.
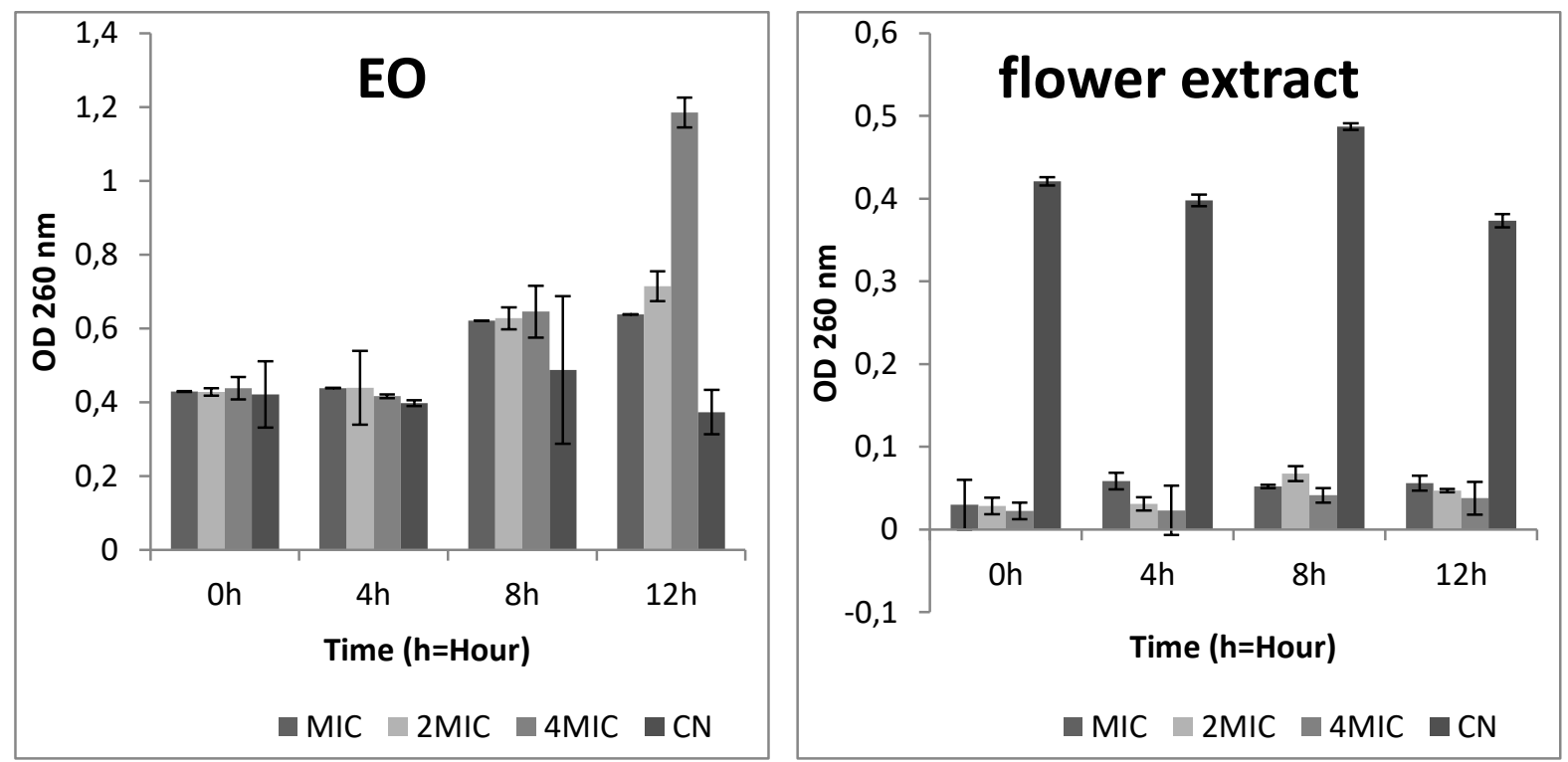

Figure 3. Release of nucleic acids by EO and flowers extract at supra-inhibitory and inhibitory concentrations 
The results exhibited the relationship between EO and the flower extract effects on releasing bacterial cellular content. The obtained data also highlighted the necessary duration to breakdown the bacterial membrane. The membrane lysis is expressed by the release of cellular content in the bacterial solution. The presence of cytoplasmic content is characterized by a change with the solution absorbance in the presence of EO and flower extracts (OD 0.4 to 1.2 and 0.02 to 0.48 respectively) successively at different times $(0-12 \mathrm{~h})$ and different inhibitory concentrations (4 MIC, 2 MIC, MIC) after the contact with E. coli. From the 8th hour, an increase of the absorbance showing the release of the nucleic acids up to 1.18 at $\mathrm{t}=12 \mathrm{~h}$ for EO and 0.48 for the flower extracts was observed. There is also a significant difference between the effect of the oil compared to that of the negative control $(\mathrm{P}$-value $<5 \%)$.

Nucleic acids were present in the cytoplasm, and their presence in the extracellular medium is an indicator of membrane damage. The results obtained showed that from $\mathrm{t}=8 \mathrm{~h}$, the release of nucleic acids becomes substantial for EO. In addition, the increase in absorbance was higher for EO compared to the flower extracts. These results indicate that EO and flower extracts could enter the bacterial cytoplasm by affecting the membrane's integrity and causing leakage of nucleic acids, hence cell death. Some researchers have shown that EOs penetrate through the cytoplasmic membrane to manifest their antimicrobial potential ${ }^{36}$. However, according to Figure 3, flower extracts did not exhibit activity on the release of nucleic acids. The results suggest that flower extracts may have another antibacterial mode of action.

\section{Conclusion}

The results obtained in this study highlight that $A$. heliotropioides exhibits antibacterial activity against E. coli ATCC25502, S. enterica NR 4311, K. pneumoniae NR4119, S. aureus NR 46375, and Salmonella typhi; with a $2 \mathrm{~h}$ cidal effect specially on E. coli. Moreover, the two extracts have similar minimum inhibitory concentrations. However, EOs are potent on membrane leakage and biofilms formation inhibition, while flower extracts may target another cell site. These results suggest that $A$. heliotropioides could serve as a source of antibacterial biomolecules.

\section{Disclosure of interests}

The authors declare that they have no competing interests.

\section{Acknowledgments}

We thank the Antimicrobial and Biocontrol Agents Unit (AmBCau), University of Yaoundé I, Université des Montagnes and the University of Douala for the facilities provided.

\section{References}

1- L. Cuzin, C. Delpierre, Épidémiologie des maladies infectieuses, EMC - Maladies infectieuses, 2005, 2, 1-5.

2- V. R. Racaniello, Emerging infectious diseases, Journal of Clinical Investigation, 2004, 113, 796-798.

3- F. Fenollar, O. Mediannikov, Emerging infectious diseases in Africa in the 21st century, New Microbes and New Infections, 2018, 26, S10-S18.

4- J. Koyama, Anti-Infective Quinone Derivatives of Recent Patents, Recent Patents on AntiInfective Drug Discovery, 2006, 1, 113-125. doi:10.2174/157489106775244073.

5- R. J. Fair, Y. Tor, Antibiotics and bacterial resistance in the 21 st century, Perspectives in Medicinal Chemistry, 2014, 25-64.

6- C. De La Fuente-Núñez, V. Korolik, M. Bains, U. Nguyen, E. B. M. Breidenstein, S. Horsman, S. Lewenza, L. Burrows, R. E. W. Hancock, Inhibition of bacterial biofilm formation and swarming motility by a small synthetic cationic peptide, Antimicrobial Agents and Chemotherapy, 2012, 56, 2696-2704.

7- I. M. Famuyide, A. O. Aro, F. O. Fasina, J. N. Eloff, L. J. McGaw, Antibacterial and antibiofilm activity of acetone leaf extracts of nine underinvestigated south African Eugenia and Syzygium (Myrtaceae) species and their selectivity indices, BMC Complementary and Alternative Medicine, 2019, 19, 1-13. doi:10.1186/s12906-019-2547-z.

8- K. Bush, Antimicrobial agents targeting bacterial cell walls and cell membranes, OIE Revue Scientifique et Technique, 2012, 31, 43-56.

9- A. S. Nayar, T. J. Dougherty, K. E. Ferguson, B. A. Granger, L. McWilliams, C. Stacey, L. J. Leach, S. Ichiro Narita, H. Tokuda, A. A. Miller, D. G. Brown, S. M. McLeod, Novel antibacterial targets and compounds revealed by a highthroughput cell wall reporter assay, Journal of Bacteriology, 2015, 197, 1726-1734.

10-J. H. Rex, B. I. Eisenstein, J. Alder, M. Goldberger, R. Meyer, A. Dane, I. Friedland, C. Knirsch, W. R. Sanhai, J. Tomayko, C. Lancaster, J. Jackson, Personal View A comprehensive regulatory framework to address the unmet need for new antibacterial treatments, The Lancet Infectious Diseases, 2013, 13, 269-275.

11-J. W. Betts, M. Hornsey, R. M. La Ragione, Novel Antibacterials: Alternatives to Traditional Antibiotics, Advances in microbial physiology, 2018, 73, 123-169. doi:10.1016/bs.amps.2018.06.001. 
12-WHO, WHO Traditional Medicine Strategy 2002-2005, In, Health, World Organization Geneva, 2002, pp, 1-74.

13-A. Romulo, E. A. M. Zuhud, J. Rondevaldova, L. Kokoska, Screening of in vitro antimicrobial activity of plants used in traditional Indonesian medicine, Pharmaceutical Biology, 2018, 56, 287-293.

14-T. Jiofack, C. Fokunang, N. Guedje, V. Kemeuze, E. Fongnzossie, B. Nkongmeneck, P. M. Mapongmetsem, N. Tsabang, Ethnobotanical uses of medicinal plants of two ethnoecological regions of Cameroon, International Journal of Medicine and Medical Sciences, 2010, 2, 60-79.

15-P. M. Mapongmetsem, B. A. Nkongmeneck, Y. V. Pinta, R. Nkuinkeu, N. Tsabang, E. Fongnzossie, V. Kemeuze, T. Jiofack, M. Johnson, S. Asaha, C. Sakwe, C. Mboufack, Etat des lieux des plantes médicinales importantes à conserver et des jardins de plantesmédicinales à promouvoir, In, Rapport CEN/OMS/MEM, , 2007, pp, 1-24.

16-M. N. L. Ngo Mback, H. Agnaniet, F. Nguimatsia, P.-M. Jazet Dongmo, J.-B. Hzounda Fokou, I. Bakarnga-via, F. Fekam Boyom, C. Menut, Optimization of antifungal activity of Aeollanthus heliotropioides oliv essential oil and Time Kill Kinetic Assay, Journal de Mycologie Medicale, 2016, 26, 233-243. doi:10.1016/j.mycmed.2016.04.003.

17-R. L. Martins, R. C. Simões, É. de M. Rabelo, A. L. F. Farias, A. B. L. Rodrigues, R. da S. Ramos, J. B. Fernandes, L. da S. Santos, S. S. M. da S. de Almeida, Chemical Composition, an Antioxidant, Cytotoxic and Microbiological Activity of the Essential Oil from the Leaves of Aeollanthus suaveolens Mart. ex Spreng, PLOS ONE, 2016, 11, e0166684.

18-J. B. Hzounda Fokou, P. M. Jazet Dongmo, I. Bakarnga-Via, M. N. L. Ngo Mback, E. Zeuko'o Memkem, A. Dior. Fall, Emmanuel. Bassene, Fabrice. Fekam Boyom, Optimized combination of Ocimum essential oils Inhibit growth of four Candida albicans, International Journal of Drug Discovery, 2014, 6, 198-206.

19-M. N. L. Ngo-Mback, C. Babii, P. M. Jazet Dongmo, M. R. Kouipou Toghueo, M. Stefan, F. Fekam Boyom, Anticandidal and synergistic effect of essential oil fractions from three aromatic plants used in Cameroon, Journal de Mycologie Medicale, 2020, 100940.

20-C. Aromdee, P. Wichitchote, N. Jantakun, Spectrophotometric determination of total lactones in Andrographis paniculata Nees. Songklanakarin J. Sci. Technol., 2005, 27, 1227-1231.

21-O. O. Odebiyi, E. A. Sofowora, Antimicrobial Alkaloids from a Nigerian Chewing Stick ( Fagara zanthoxyloides ), Journal of Medicinal Plant Research, 1979, 36, 204-207.
22-A. Sofowora, E. Ogunbodede, A. Onayade, The role and place of medicinal plants in the strategies for disease prevention., African journal of traditional, complementary, and alternative medicines : AJTCAM / African Networks on Ethnomedicines, 2013, 10, 210-229.

23-W. Evans, Trease and Evans' pharmacognosy, 13th ed. Bailliere Tindall: London, Philadelphia, 1989.

24-P. R. Adams, Identification of essential oil components by gas chromatography/mass spectrometry, Allured Pu. 2007.

25-M. A Wikler, Methods for dilution antimicrobial susceptibility tests for bacteria that grow aerobically: approved standard. CLSI (NCCLS), 2006, 26, M7-A7.

26-F. Lewisoscar, D. Mubarakali, C. Nithya, R. Priyanka, V. Gopinath, N. S. Alharbi, N. Thajuddin, Biofouling: The Journal of Bioadhesion and Biofilm One-pot synthesis and anti-biofilm potential of copper nanoparticles (CuNPs) against clinical strains of Pseudomonas aeruginosa, Biofouling, 2015, 31, 379-391.

27-Y. L. Tang, Y. H. Shi, W. Zhao, G. Hao, G. W. Le, Insertion mode of a novel anionic antimicrobial peptide MDpep5 (Val-Glu-Ser-TrpVal) from Chinese traditional edible larvae of housefly and its effect on surface potential of bacterial membrane, Journal of Pharmaceutical and Biomedical Analysis, 2008, 48, 1187-1194.

28-T. Ngouana, C. Mbouna, R. Kuipou, M. Tchuenmogne, E. Zeuko'o, V. Ngouana, M. Mallié, S. Bertout, F. Boyom, Potent and Synergistic Extract Combinations from Terminalia Catappa, Terminalia Mantaly and Monodora tenuifolia Against Pathogenic Yeasts, Medicines, 2015, 2, 220-235.

29-E. Simionatto, C. Porto, C. Z. Stüker, I. I. Dalcol, U. F. Da Silva, Chemical composition and antimicrobial activity of the essential oil from Aeolanthus suaveolens Mart. ex Spreng, Quimica Nova, 2007, 30, 1923-1925.

30-M. Aminzadeh, F. Amiri, E. A. Abadi, K. Mahdevi, S. Fadai, Factors affecting on essential chemical composition of Thymus kotschyanus in Iran, World Applied Sciences Journal, 2010, 8, 847-856.

31-M. Cristani, M. D'Arrigo, G. Mandalari, F. Castelli, M. G. Sarpietro, D. Micieli, V. Venuti, G. Bisignano, A. Saija, D. Trombetta, Interaction of four monoterpenes contained in essential oils with model membranes: Implications for their antibacterial activity, Journal of Agricultural and Food Chemistry, 2007, 55, 6300-6308.

32-M. Kong, X. G. Chen, C. S. Liu, C. G. Liu, X. H. Meng, L. J. Yu, Antibacterial mechanism of chitosan microspheres in a solid dispersing system against E. coli, Colloids and Surfaces B: Biointerfaces, 2008, 65, 197-202. 
33-M. M. Bazargani, J. Rohloff, Antibiofilm activity of essential oils and plant extracts against Staphylococcus aureus and Escherichia coli biofilms, Food Control, 2016, 61, 156-164.

34-S. W. Kim, I. M. Chang, K. B. Oh, Inhibition of the Bacterial Surface Protein Anchoring Transpeptidase Sortase by Medicinal Plants, Bioscience, Biotechnology and Biochemistry, 2002, 66, 2751-2754.

35-S. Mizunaga, T. Kamiyama, Y. Fukuda,
M. Takahata, J. Mitsuyama, Influence of inoculum size of Staphylococcus aureus and Pseudomonas aeruginosa on in vitro activities and in vivo efficacy of fluoroquinolones and carbapenems, Journal of Antimicrobial Chemotherapy, 2005, 56, 91-96.

36-F. Bakkali, S. Averbeck, D. Averbeck, M. Idaomar, Biological effects of essential oilsA review, Food and Chemical Toxicology, 2008, $46,446-475$. 